\title{
Biosynthetic Pathways to Glycosidase Inhibitors
}

\author{
Fernando Gomollón-Bel, Ignacio Delso, Tomás Tejero and Pedro Merino*
}

Laboratorio de Síntesis Asimétrica. Departamento de Síntesis y Estructura de Biomoléculas. Instituto de Síntesis Química y Catálisis Homogénea (ISQCH). Facultad de Ciencias. Universidad de ZaragozaCSIC. Campus San Francisco. 50009 Zaragoza, Aragón. Spain

\begin{abstract}
Glycosidase inhibitors are important compounds that can interfere with several biosynthetic processes including $N$-linked glycosylation and the biosynthesis of several glycoproteins. Understanding the biogenesis of naturally occurring glycosidase inhibitors would be a crucial step towards the chemical synthesis of analogues of choice. This review focuses on the current knowledge regarding the biosynthesis of a series of polyhydroxylated saturated nitrogen heterocycles including nojirimycin and swainsonine among others, with a potent biological activity as inhibitors of glycosidases and transglycosidases.
\end{abstract}

\section{KEYWORDS}

Biosynthesis / Glycosidase Inhibitors / Nojirimycin / Deoxynojirimycin / Swainsonine 


\section{Introduction}

Glycosydase inhibitors are a rapidly growing family of molecules mostly consisting of polyhydroxylated mono- and bicyclic saturated nitrogen heterocycles commonly referred to as iminosugars (Figure 1).[1-3] Compounds like nojirimycin 1, 1deoxynojirimycin 2, DMDP 3, castanospermine $\mathbf{4}$ or swainsonine $\mathbf{5}$ and their derivatives play crucial roles in the biological activities of some pharmaceutically important compounds. [4-6]

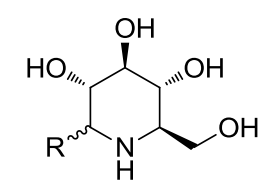

$1 \mathrm{R}=\mathrm{OH}$ nojirimycin

$2 \mathrm{R}=\mathrm{H}$ 1-deoxynojirimycin

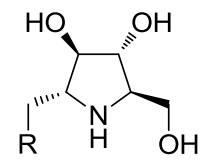

$3 \mathrm{R}=\mathrm{OH}$ DMDP

$4 \mathrm{R}=\mathrm{H}$ 6-deoxyDMDP

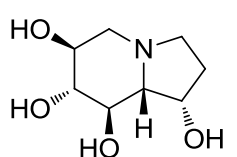

5 castanospermine<smiles>OC[C@H]1[C@@H](O)[C@@H](O)[C@H]2[C@@H](O)CN12</smiles>

9 casuarine

Figure 1. Glycosidase inhibitors

Nojirimycin 1 was originally isolated from cultures of several strands of Streptomyces [7,8] and Bacillus[9] and 1-deoxynojirimycin was isolated from plants of genus Morus.[10] Compounds $\mathbf{1}$ and $\mathbf{2}$ inhibit various glycosidases having important effects on the biosynthesis of membrane and secretory glycoproteins.[11] DMDP 3 can be isolated from the cyanobacterial genus Cylindrospermum and it is capable of effectively inhibiting digestive glycosidases.[12] The 6-deoxyderivative $\mathbf{4}$ has been isolated from Angylocalyx pynaertii and in contrast to other polyhydroxylated pyrrolidines it was found to be unique in inhibiting $\beta$-mannosidase.[13] Castanospermine 5 was first isolated from the seeds of Castanosperma australe[14] and it has demonstrated antiviral activity.[15,16] It is also known that castanospermine interfere with the metabolism of glycogen[17] and it inhibits several glycosidases.[18] Swainsonine 6 was first isolated from swainsona in Australia but it is also present in numerous plants and fungi. Compound 6 has antitumoral activity[19,20] although some clinical trials were discouraging.[21] Other natural pyrrolidine alkaloids like alexine 7, australine $\mathbf{8}$ and casuarine $\mathbf{9}$ have also been isolated from plants and microorganisms.[22] 
Calystegines were found in the medicinal plant Atropa belladonna and consist of a nortropane skeleton with three or four hydroxyl groups (Figure 2). There are up to 14 different structures of natural occurring calystegines isolated from a variety of vascular plants. They cannot be found in fungi or microorganisms. The chemistry and biology of calystegines including chemotaxonomy, biological activity and some insights on the biogenesis in the context of co-occurrence with tropane alkaloids have been compiled by Dräger in an excellent review[23] and a chapter book,[24] covering literature from 1998 to middle 2003 and up to 2007, respectively. Since then there has not been relevant communications in the topic; so, in this review calystegines will not be treated and for previous work the reader is directed to the above mentioned reviews.

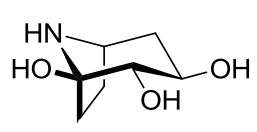

10 calystegin $A_{3}$

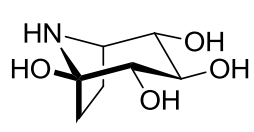

10 calystegin $B_{2}$

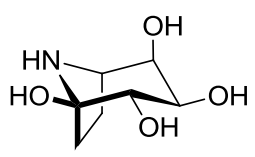

10 calystegin $B_{4}$

Figure 2. Calystegines

The interest in glycosidase inhibitors has increased enormously during the past two decades and the number of synthetic approaches to their preparation is extremely extensive and growing at a rapid rate.[25,26] One reason for this huge synthetic activity is the great variety of biological activity against different enzymes that can be found depending on the absolute configuration of the stereogenic centers bearing the hydroxyl groups.

The mechanism of the various existing glycosidases is known to proceed through oxocarbenium-like transition structures[27,28] and it is well-accepted that inhibition of typical glycosidase inhibitors occur because such sugar mimics resemble the structural features of the transition state.[29] Different configurations as well as conformational restrictions in inhibitors help to a better recognition by the enzyme contributing to a higher inhibition activity.[30]

In the large group of glycosidase inhibitors, synthetic studies have already been highlighted in several classes,[31-33] e.g. for pyrrolidines,[34,35] piperidines,[36,37] bicyclic compounds such as indolizidines[38] and pyrrolizidines[39,40] and imino disaccharides.[41,42] However, only a little is known about biosynthetic routes towards that sort of compounds. It can be expected that the knowledge of the biosynthetic 
pathways can be used to manipulate the metabolite pattern of involved microorganisms, directing the fermentation process to produce desired metabolites.

In this review, we summarize the current knowledge regarding the biosynthesis of naturally occurring glycosidase inhibitors. Semisynthetic studies on the structural and pharmaceutical properties of these compounds have been extensively reported and will not be covered here. Similarly, for detailed information of natural occurrence of discussed molecules and precise synthetic approaches the reader is referred to previous reviews. On the other hand, experimental evidences supporting the existence of various routes in microorganisms will be discussed.

\section{Biosynthesis of monocyclic compounds. Piperidines and pyrrolidines}

Nojririmycin 1 has been isolated from a variety of microorganisms including $S$. roseochromogenes, S. lavendulae, S. nojiriensis and S. subrutilus. The last one, when grown on a glucose-containing soyabean medium produces both 1deoxymannojirimycin and 1-deoxynojirimycin. Experiments with deuterated glucose showed incorporation of deuterium at C-6 in both alkaloids indicating that the first step in the biosynthesis of both iminosugars is the isomerization of glucose to fructose. Accordingly, it is proposed mannojirimycin $\mathbf{1 7}$ as the first iminosugar to be formed.[43]

In fact, when 6,6- $\left[{ }^{2} \mathrm{H}_{2}\right]$-glucose was employed, NMR analysis of deuterium labellled 1-deoxynojirimycin 2 showed that only the equatorial proton at $\mathrm{C}-1$ had been replaced by deuterium, in agreement with the oxidation of the primary hydroxyl group at C-6 in fructose to give $\mathbf{1 3}$ with the loss of one hydrogen atom. The introduction of the amino group is certainly unknown and three ways are possible through derivatives 1416, all of them being possible precursors of mannojirimycin 17.[44] Elimination of water from 17 and further reduction afforded the observed 1-deoxymannojirimycin 19. This route was confirmed by using $5-\left[{ }^{2} \mathrm{H}\right]$-glucose in the fermentation. Under such conditions deuterium was only incorporated at C-2 in mannojirimycin 17 . The 1deoxynojirimycin 2 obtained in this experiment did not show incorporation of deuterium. This is in agreement with the hypothesis that either mannojirimycin $\mathbf{1 7}$ or its 1-deoxy derivative 19 are precursors in the biosynthetic scheme, since loss of hydrogen isotope from C-2 would be expected upon epimerization of $\mathbf{1 7}$ or 19. Further experiments with deuterated substrates deomonstrated that epimerization occurs predominantly at nojirimycin level, i.e. between $\mathbf{1 7}$ and $\mathbf{1}$. It had been reported that 1deoxynojirimycin 2 could be epimerized to 1-deoxymannojirimycin 19 by a strain of 
Agrobacterium sp. trough an oxidation to a cyclic ketocompound followed by reduction to give the epimeric derivative. However, by considering this hypothesis it is difficult to justify the presence of nojirimycin $\mathbf{1}$.<smiles>CC(C)OC(O)C(O)C(O)C(O)CO</smiles>

D-glucose<smiles>O=C(CO)[C@@H](O)[C@H](O)[C@H](O)CO</smiles>

D-fructose reductive amination<smiles>N[C@@H](CO)[C@@H](O)[C@H](O)[C@H](O)CO</smiles>

14

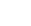

1<smiles>N[C@@H](CO)[C@@H](O)[C@H](O)[C@H](O)C=O</smiles><smiles>O=C[C@H](O)[C@@H](O)[C@H](O)C(=O)CO</smiles>

D-fructose

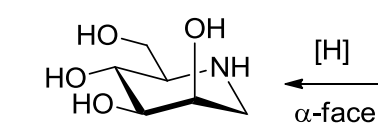

19 1-Deoxymannojirimycin

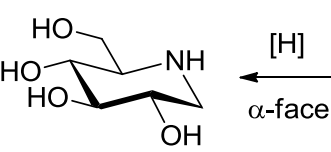

2 1-Deoxynojirimycin

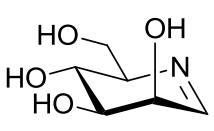

18
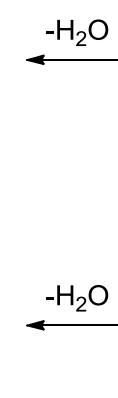

20
15

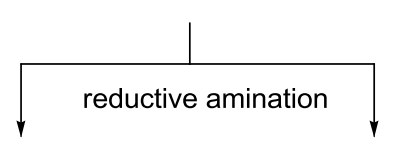<smiles>NC[C@H](O)[C@H](O)[C@H](O)C(=O)CO</smiles>

16
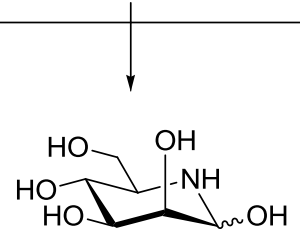

17 Mannojirimycin
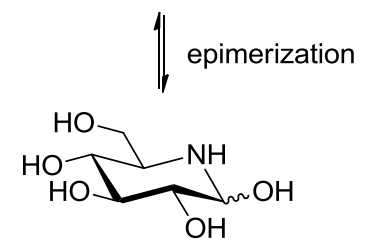

1 Nojirimycin

Scheme 1. Biosynthesis of mannojirimycin 17, nojirimycin 1 and their deoxy derivatives 19 and 2 from D-glucose in Streptomyces subrutilus

Similar experiments carried out with Bacillus subtilis var niger only produced 1deoxynojirimycin 2 and no traces of 1-deoximannojirimycin 19 were found.[45] Also in this case, labeling studies demonstrated that glucose is the precursor of 1deoxynojirimycin 2. Additional enzyme assays and labeling studies supported that both mannojirimycin 17 and nojirimycin 1 are intermediates in the biosynthesis of 1deoxynojirimycin 2.

Recently, the complete genome sequence of Bacillus amiloliquefaciens has been determined[46] and a gene cluster that initiates the biosynthesis of 2 in such microorganism has been identified and provided further evidence for the pathway illustrated in Scheme 1.[47] Additionally, three enzymes involved in the first steps of 
the biosynthesis have also been identified. Noteworthy, the same gene cluster has been found in Bacillus atrophaeus [48] as well as in Bacillus subtilis,[49] known producers of 1-deoxynojirimycin $\mathbf{1}$.

The biosynthetic route to 1-deoxynojirimycin $\mathbf{2}$ is, however, different for higher plants as demonstrated by Shibano and co-workers.[50] These authors studied the biosynthesis of 2 by using 1-[ $\left.{ }^{13} \mathrm{C}\right]$-glucose in the higher plant Commelia communis. While a significant ${ }^{13} \mathrm{C}$ enrichment was observed at C-6 for compound 2 obtained in microorganisms, in the case of that being produced in plants the ${ }^{13} \mathrm{C}$ enrichment was located at C-1. These experiments resulted in the proposal outlined in Scheme 2. According to this hypothesis C-1/C-5 cyclization is produced in the original glucose molecule without any type of inversion. Additional support was provided by the fact that the same ${ }^{13} \mathrm{C}$ enrichment was observed in fructose obtained from administration of $1-\left[{ }^{13} \mathrm{C}\right]$-glucose.

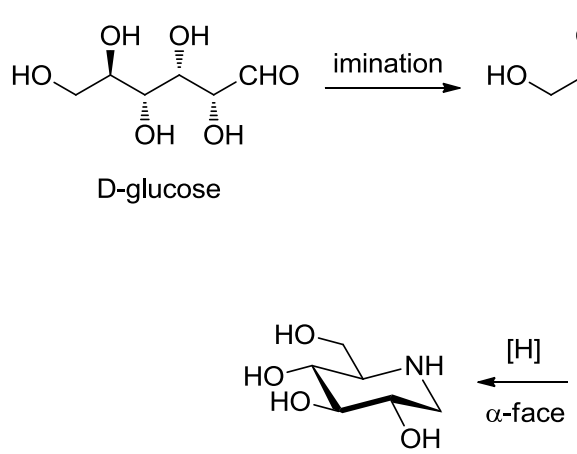

2 1-Deoxynojirimycin

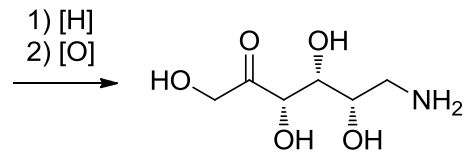

22

21

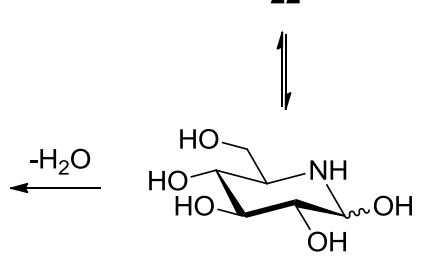

1 Nojirimycin

Scheme 2. Biosynthesis of nojirimycin 1 and1-deoxynojirimycin 2 from D-glucose in Commelia communis.

When imination is produced on fructose, formed by isomerization of glucose, the same process led to DMDP 3 (Scheme 3). Indeed, compound 3 is obtained from 1- $\left[{ }^{13} \mathrm{C}\right]-$ glucose under the same conditions employed for the preparation of 1-deoxynojirimycin 2.[50] 


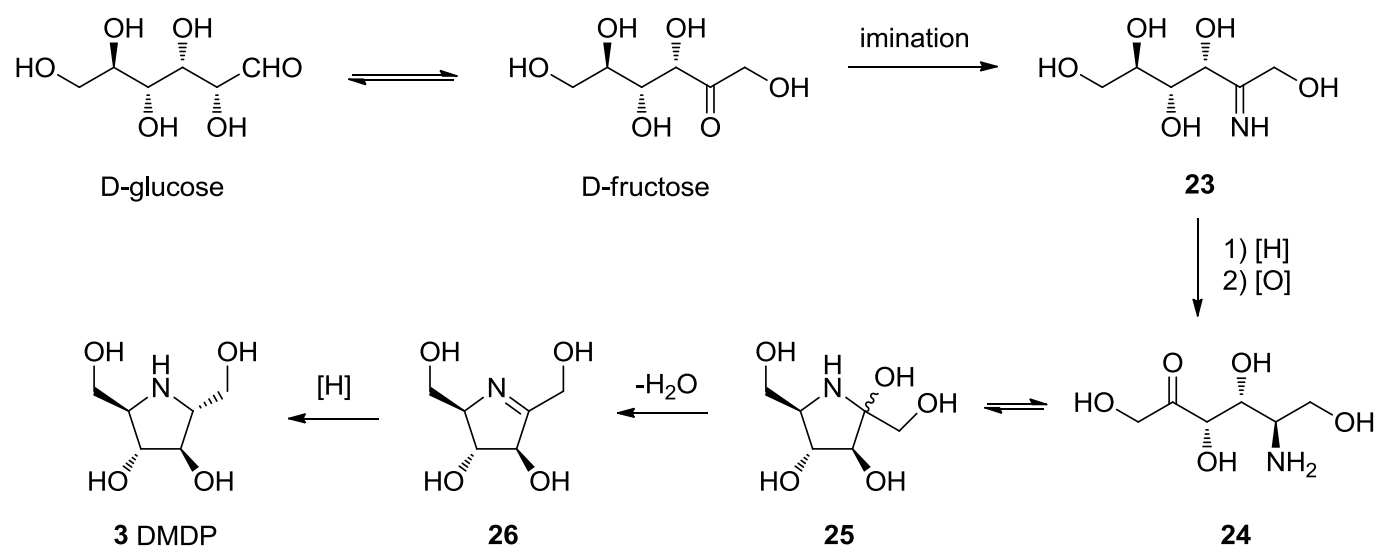

Scheme 3. Biosynthesis of DMDP 3 from D-glucose in Commelia communis.

Broussonetines are polyhydroxylated pyrrolidines bearing a long carbon chain at C-2. They have been isolated from Broussonetia kazinoki.[51] ${ }^{13} \mathrm{C}$ NMR spectroscopy studies after feeding experiments using 1-[ $\left[{ }^{13} \mathrm{C}\right]$-glucose demonstrated that broussonetine J 27 is synthesized through routes similar to those of sphingosine and phytosphingosines.[52] Similar results were obtained for broussonetines C 28 and E 29.

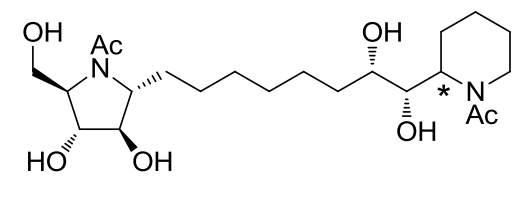

27 Broussonetine $\mathrm{J}$<smiles></smiles>

28 Broussonetine E<smiles></smiles>

29 Broussonetine C

Figure 3. Broussonetines

Accordingly, in the case of broussonetines, it is assumed that after typical transformation of D-glucose into serine by well-known metabolic routes[53,54] the introduction of the side chain is achieved by condensation of serine with palmitoylCoA. The labeling pattern found in the side chain also indicated that the palmitoyl fragment was formed through the acetate-malonate pathway (Scheme 4). The absolute configuration of the pyrrolidine moieties in most broussonetines is related to D-serine except in the case of broussonetine $\mathrm{U} \mathbf{3 0}$ in which is related to L-serine. 


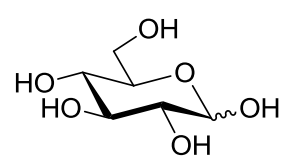

D-Glucose<smiles>C=CC(=O)OCC(=O)OCC(O)COCC</smiles><smiles>CC(C)C(=O)OCC(=O)C(=O)O</smiles>

\begin{tabular}{l|l} 
serine palmitoyl \\
transferase
\end{tabular}$\prod_{O}^{C O A S} \mathrm{C}_{15} \mathrm{H}_{31}$

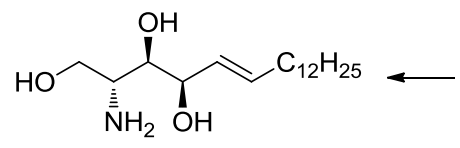

32<smiles>NC(CO)C(=O)c1ccccc1</smiles>

31

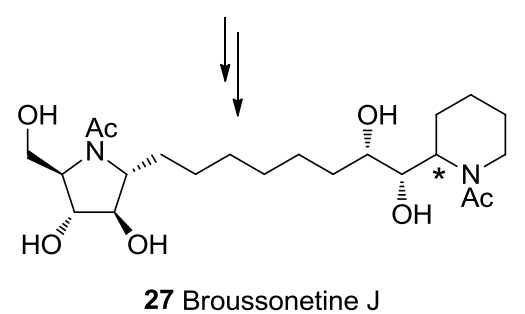

Scheme 4. Biosynthesis of broussonetine J from D-glucose in Broussonetia kazinoki.

\section{Biosynthesis of bicyclic compounds. Indolizidines.}

The biosynthesis of the piperidine nucleus of bicyclic iminosugars starts with the production of pipecolic acid, which is the precursor of several compounds such as swainsonine or slaframine. Pipecolic acid was found to be a product of lysine catabolism in animals, microorganisms and plants. Grobbelaar and Steward established the transformation oflysine into pipecolic acid through route A (Scheme 5) by using labeled lysine in bean plants Phaseolus vulgaris.[55] According to their findings the nitrogen of the pipecolic acid should be supplied by the $\alpha$-amino group of the lysine.<smiles>NCCCCCC(N)C(=O)O</smiles>

L-lysine

$\alpha$-amino
oxidase<smiles>NCCCCC(=O)C(=O)O</smiles>

35

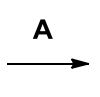<smiles>NC(CCCC=O)C(=O)O</smiles>

33<smiles>O=C(O)C1=NCCCC1</smiles>

36

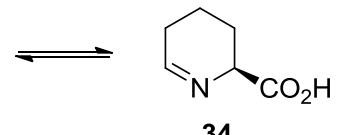

34

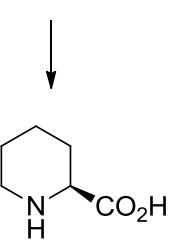

37 pipecolic acid

Scheme 5. Biosynthesis of pipecolic acid from lysine. 
On the other hand, Gupta and Spenser demonstrated that in rats the conversion of lysine into pipecolic acid proceeds via $\varepsilon$-amino- $\alpha$-ketocapric acid 35.[56] This mechanism indicated that the nitrogen atom of the pipecolic acid should be supplied by the $\varepsilon$-amino group of lysine (Scheme 5, route B). Similar experiments carried out with Neurospora crassa and Phaseolus vulgaris afforded identical results being in conflict with previous findings. Further studies in animals and plants demonstrated that both routes A and B, illustrated in Scheme 5, distinguishable at the loss of a particular amino group of the lysine, are possible. In fact, there are several experimental evidences supporting the existence of various routes in microorganisms, as well as specific enzymes involved in some steps. This topic has been reviewed elsewhere[57] and the reader is referred to that publication for more details concerning the biosynthesis of pipecolic acid.

The biosynthesis of slaframine $\mathbf{4 2}$ has been studied in Rhizoctonia leguminicola a fungus that causes black spot disease of red clover.[58] By using radiolabelled 1$\left[{ }^{14} \mathrm{C}\right]$-lysine and 6-[ $\left[{ }^{14} \mathrm{C}\right]$-lysine it has been demonstrated their incorporation into slaframine.[59] Moreover, that incorporation was efficiently blocked by adding pipecolic acid, thus indicating that pipecolic acid is an intermediate in the prcess of biogenesis. The same authors also studied the origin of pipecolic acid in Rhizoctonia leguminicola and verified the biosynthetic pathway illustrated in Scheme 5.[60] Further experiments with radiolabelled pipecolic acid showed incorporation of radioactivity to slaframine in the expected positions.

The origin of the pyrrolidine ring of slaframine was also investigated[61] and it was found to be formed from malonic acid and acetic acid. Spectrometric analysis of radiolabelled/deuterated compounds indicated that the methyl carbon of acetate is joined to the carboxyl carbon of the pipecolate. These results suggest the formation of intermediate 38 by acylation of malonate with pipecolic acid (Scheme 6). Furthermore, preparation of deuterated $\mathbf{4 0}$ allowed to identify this compound as an advanced intermediate in the biogenesis of slaframine[62] and to propose 1oxooctahydroindolizine 39 as the intermediate precursors of $\mathbf{4 0}$. In addition to slframine 42, swainsonine 6 was also isolated from Rhizoctonia leguminicola.[63] By employing perdeutero pipecolic acid it was demonstrated that both slaframine and swainsonine have common precursors in their biogenesis.[64] 


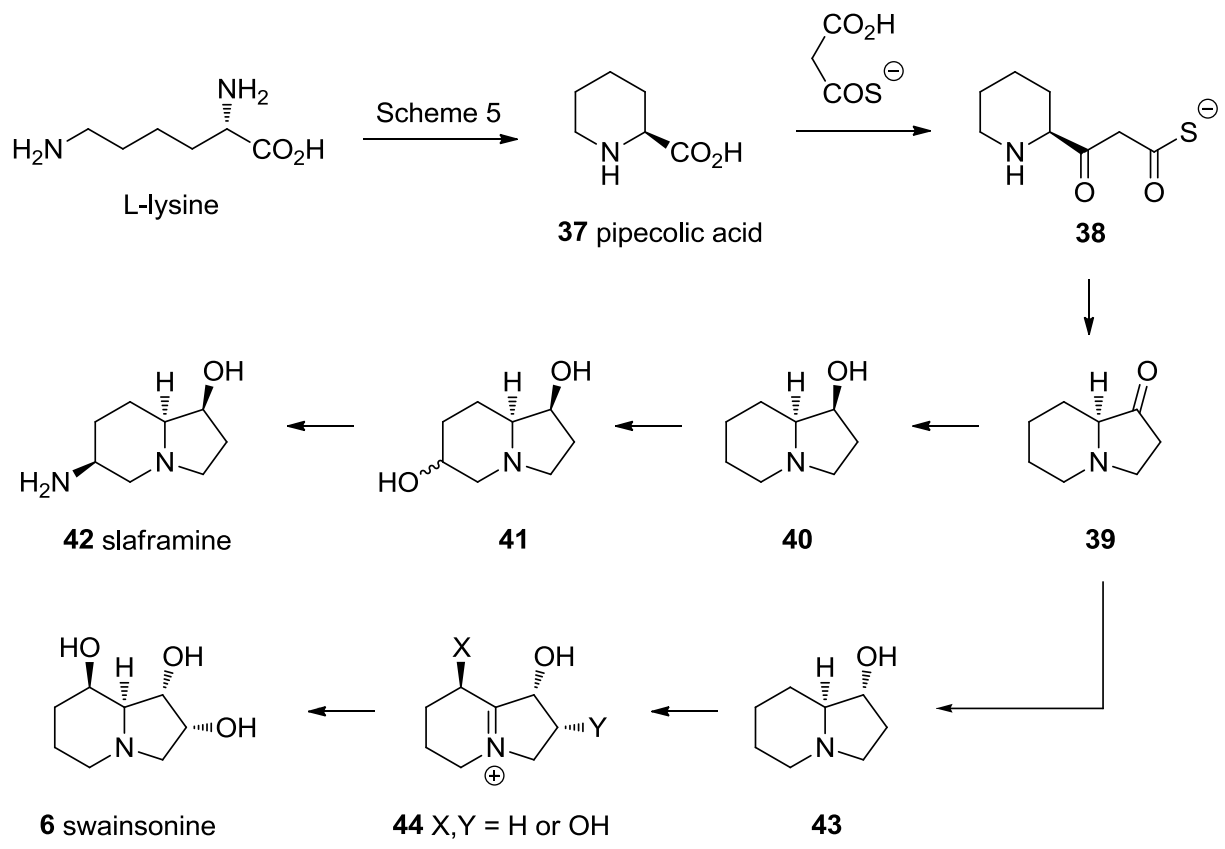

Scheme 6. Biogenesis of slaframine from lysine in Rhizoctonia leguminicola

In the case of swainsonine, compound 39 is reduced by the other face providing 43. Oxidation at C-8a of this intermediate should be postulated, probably through an iminium ion, with subsequent reduction by the appropriate face to provide the $R$ configuration of swainsonine 6 (Scheme 6). Further experiments with deuterated compounds allowed to corroborate that hypothesis.[65]

The biosynthesis of swainsonine $\mathbf{6}$ has also been studied in plants. In particular, studies carried out with Astragalux oxyphysus showed that swainsonine $\mathbf{6}$ is biosynthesized in that plant by a very similar pathway (if not identical) to that in the fungus by incorporating pipecolic acid into the swainsonine skeleton.[66] On the other hand, it has been observed that the plant does not produce slaframine 42; neither does it produce intermediates $\mathbf{4 0}$ and $\mathbf{4 1}$.

The role of both pipecolic acid and malonic acid in the biosynthesis of swainsonine $\mathbf{6}$ has also been pointed out by stimulating production of such alkaloid by transformed root cultures of Swainsona galegifolia.[67]

\section{Conclusions}

Polyhydroxylated saturated nitrogen heterocyles provided a variety of biosynthetic challenges. Up to now, several aspects related to their biogenesis have been revealed. However, there is still much work to do. Further investigations are still required to clarify the biosynthetic enzymes involved in the catalytic processes. Such enzymes 
should be of a great value for enzymatic approaches to iminosugars and their biomimetic synthesis. There are experimental evidences indicating that different biosynthetic mechanisms operate on diverse microorganisms (for instance Bacillus subtilis vs. Streptomyces subrutilus for 1-deoxynojirimycin) or higher plants. Very recently, a gene cluster has been identified providing evidence of the biosynthetic pathways. In this regard, the catalytic mechanism of individual domains should continue to be probed by using standard mutagenesis techniques with studies involving purified enzymes. By acquiring this knowledge it will be possible to design new analogues by developing more sophisticated and improved strains. The fields of synthetic organic chemistry and biochemistry will be united by employing new bioorganic tools for further chemical elaboration of new compounds of pharmaceutical interest.

\section{Acknowledgments}

This study was supported by the Ministerio de Ciencia e Innovacion (MICINN) and FEDER Program (Madrid, Spain, project CTQ2010-19606) and the Gobierno de Aragon (Zaragoza, Spain, Bioorganic Chemistry Group. E-10). F.G.-B. thanks CSIC for a JAE predoctoral grant.

\section{References}

[1] Nash RJ, Asano N, Watson AA. In: Pelletier SW, Ed. Alkaloids: Chemical and Biological perspectives. Oxford: Elsevier 1996; 345-76.

[2] Nishimura Y. In: Atta-ur-Rahman, Ed. Studies in natural products chemistry. Oxford: Elsevier 1999; 495-583.

[3] Asano N. Glycosidase inhibitors: update and perspectives on practical use. Glycobiology 2003; 13: 93R-104R

[4] Stütz, AE, Ed. Iminosugars as glycosidase inhibitors. Nojirimycin and beyond Weinheim: Wiley-VCH 1999

[5] Compain P. Martin OR, Eds. Iminosugars. From synthesis to therapeutic applications. Chichester: John Wiley \& sons 2007 
[6] Winchester BG. Iminosugars: from botanical curiosities to licensed drugs. Tetrahedron: Asymmetry 2009; 20: 645-51

[7] Ishida N, Kumagai K, Niida T, Tsuruoka T, Yumoto H. Nojirimycin, a new antibiotic. II. Isolation, characterization and biological activity. J. Antibiot. Ser. A, 1967; 20: 66-71.

[8] Inouye S, Tsuruoka T, Ito T, Niida T. Structure and synthesis of nojirimycin. Tetrahedron $1968 ; 24 ; 2125-44$

[9] Schmidt DD, Frommer W, Muller L, Truscheit E. Glucosidase inhibitors from Bacilli. Naturwissenschaften 1979; 66: 584-5.

[10] Yagi, M.; Kouno, T.; Aoyagi, Y.; Murai, H. The structure of moranoline, a piperidine alkaloid from Morus species. Nippon Nogei Kagaku Kaishi 1976; 50: 571-2. [11] Peyrieras N, Bause E, Legler G, Vasilov L, Claesson L, Peterson P, Ploegh H. Effects of the glucosidase inhibitors nojirimycin and deoxynojirimycin on the biosynthesis of membrane and secretory glycoproteins. EMBO J 1983; 2: 823-32. [12] Juttner F, Wessel HP. Isolation of di(hydroxymethyl)dihydroxypyrrioldine from the cyanobacterial genus Cyclindrospermum. J Phycol 2003; 39: 26-32 [13] Molyneux RJ, PanYT, H.; Tropea JE, Elbein AD, Lawyer CH, Hughes DJ, Fleet GWJ. 2-hydroxymethyl-3,4-dihydroxy-6-methyl-'yrroline (6-deoxy-DMDP), an alkaloid beta-mannosidase inhibitor from seeds of angylocalyz pynaertii. J Nat Prod 1993; 56: 1356-1364

[14] Hohenschutz LD, Bell AE, Jewess PJ, Leworthy DP, Pryce RJ, Arnold E, Clardy J. Castanospermine, a 1,6,7,8-tetrahydroxyoctahydroindolizine alkaloid, from seeds of Castanospermum australe Phytochemistry 1981; 20: 811-4. 
[15] Whitby K, Pierson TC, Geiss B, Lane K, Engle M, Zhou Y, Doms RW,

Diamond MS. Castanospermine, a potent inhibitor of dengue virus infection in vitro and in vivo. J Virol. 2005; 79: 8698-706.

[16] Walker BD, Kowalski M, Goh WC, Kozarsky K, Krieger M, Rosen C, Rohrschneider L, Haseltine WA, Sodroski J. Inhibition of human immunodeficiency virus syncytium formation and virus replication by castanospermine. PNAS 1987; 84: $8120-4$

[17] Saul R, Ghidoni JJ, Molyneaux RJ, Elbein AD. Castanospermine inhibits alphaglucosidase activities and alters glycogen distribution in animals. PNAS 1985; 82: 9397.

[18] Saul R, Chambers JP, Molyneaux RJ, Elbein AD. Castanospermine, a tetrahydroxylated alkaloid that inhibits $\beta$-glucosidase and $\beta$-glucocerebrosidase. Arch Biochem Biophys 1983; 221: 593-5.

[19] Sun JY, Zhu MZ, Wang SW, Miao S, Xie YH, Wang JB. Inhibition of the growth of human gastric carcinoma in vivo and in vitro by swainsonine. Phytomedicine: Int J Phytother Phytopharm 2007; 14: 353-9.

[20] Sun YJ, Yang H, Miao S, Li JP, Wang SW, Zhu MZ, Xie YH, Wang JB, Liu Z, Yang Q. Suppressive effects of swainsonine on C6 glioma cell in vitro and in vivo. Phytomedicine: Int J Phytother Phytopharm 2009; 16: 1070-4.

[21] Shaheen PE, Stadler W, Elson P, Knox J, Winquist E, Bukowski RM. Phase II study of the efficacy and safety of oral GD0039 in patients with locally advanced or metastasic renal cell carcinoma. Investig New Drugs 2005; 23: 577-81.

[22] For an excellent and comprehensive review on the natural occurrence of a great variety of sugar-mimic glycosidase inhibitors see: Asano N, Nash RJ, Moylneux RJ, Fleet GWJ. Sugar-mimic glycosidase inhibitors: natural occurrence, biological activity 
and prospects for therapeutic application. Tetrahedron: Asymmetry 2000; 11: 16451680.

[23] Dräger B. Chemistry and biology of calystegines. Nat Prod Rep 2004; 21: 21123.

[24] Biastoff S, Dräger B. In: Cordell GA. Ed, The alkaloids. Chemistry and Biology. New York: Academic Press 2007; 49-102.

[25] Compain P, Chagnault V, Martin OR. Tactics and strategies for the synthesis of iminosugar C-glycosides: a review. Tetrahedron: Asymmetry 2009, 20, 672-711.

[26] Cipolla L, Ferla BL, Gregori M. Combinatorial approaches to iminosugars as glycosidase and glycosyltransferase inhibitors. Comb Chem High Throug Screen 2006; 9: 571-82.

[27] Zechel DL, Whiters SG. Glycosidase Mechanisms: Anatomy of a Finely Tuned Catalyst. Acc. Chem. Res. 2000, 33, 11-18.

[28] Rye CS, Withers SG. Glycosidase mechanisms Curr Opin Chem Biol 2000; 4: 573-80.

[29] Gloster TM, Davies GJ. Glycosidase inhibition: assessing mimicry of the transition state. Org Biomol Chem 2010; 8: 305-20.

[30] Gloster TM, Madsen R, Davies GJ. Dissection of conformationally restricted inhibitors binding to a beta glucosidase ChemBioChem 2006; 7: 738-42.

[31] Davis BG. A silver-lined anniversary of Fleet iminosugars: 1984-2009, from DIM to DRAM to LABNAc Tetrahedron: Asymmetry 2009; 20: 652-71.

[32] Lillelund VH, Jensen HH, Liang X, Bols M. Recent Developments of Transition-State Analogue Glycosidase Inhibitors of Non-Natural Product Origin Chem Rev 2002; 102: 515-53. 
[33] Tatsuka K In: Chapelur, Y. Ed, Carbohydrate mimics. Weinheim: Wiley-VCH. 1998, 283-305.

[34] Stocker BL, Dangerfield EM, Win-Mason AL, Haslett GW, Timmer MSM. Recent Developments in the Synthesis of Pyrrolidine-Containing Iminosugars. Eur J Org Chem 2010; 1615-37.

[35] Ayad T, Genisson Y, Baltas M. Chemical Approaches Towards Synthesis of Some Naturally Occurring Iminosugars. Curr Org Chem 2004; 8: 1211-33.

[36] Pearson MSM, Mathe-Allainmat M, Fargeas V, Lebreton J. Recent Advances in the Total Synthesis of Piperidine Azasugars Eur J Org Chem 2005; 2159-91.

[37] Dragutan H, Dragutan V, Demonceau A. Targeted drugs by olefin metathesis: piperidine-based iminosugars. RSC Advances 2012; 2: 719-36.

[38] Kim IS, Jung YH. Recent Advances in the Total Synthesis of Indolizidine Iminosugars Heterocycles 2011; 83: 2489-507.

[39] Pyne SG. Recent developments on the synthesis of (-)-swainsonine and analogues. Curr Org Synth 2005; 2: 39-57.

[40] Brandi A, Cardona F, Cicchi S, Cordero FM, Goti A. Stereocontrolled Cyclic Nitrone Cycloaddition Strategy for the Synthesis of Pyrrolizidine and Indolizidine Alkaloids. Chem Eur J 2009; 15: 7808-21.

[41] Merino P, Delso I, Marca E, Tejero T, Matute R. Chemistry and Biology of Iminosugar Di- and Oligosaccharides. Curr Chem Biol 2009; 3: 253-71.

[42] Robina I, Vogel P. Synthesis of aza-C-disaccharides (dideoxyimino-alditols Clinked to monosaccharides) and analogues. Synthesis 2005; 675-702.

[43] Hardick DJ, Hutchinson DW, Trew SJ, Wellington, EMH. The biosynthesis of deoxynojirimycin and deoxymannonojirimycin in Streptomyces subrutilus. Chem Commun 1991; 729-30. 
[44] Hardick DJ, Hutchinson DW, Trew SJ, Wellington EMH. Glucose is a Precursor of 1-deoxynojirimycin and 1-deoxymannonojirimycin in Streptomyces subrutilus. Tetrahedron 1992; 48: 6285-96.

[45] Hardick DJ, Hutchinson DW. The Biosynthesis of 1-Deoxynojirimycin in Bacillus subtilis var niger Tetrahedron 1993; 49: 6707-10.

[46] Chen XH, Koumoutsi A, Scholz R, Eisenreich A, Schneider K, Heinemeyer I, Morgenstern B, Voss B, Hess WR, Reva O, Junge H, Voigt B, Jungblut PR, Vater J, Sussmuth R, Liesegang H, Strittmatter A, Gottschalk G, Borriss R. Comparative analysis of the complete genome sequence of the plant growth-promoting bacterium Bacillus amyloliquefaciens FZB42 Nat. Biotech. 2007, 25, 1007-14.

[47] Clark LF, Johnson JV, Horenstein NA. Identification of a Gene Cluster that Initiates Azasugar Biosynthesis in Bacillus amyloliquefaciens. ChemBioChem 2011; 12: 2147-50.

[48] Gibbons HS, Broomall S, McNew LA, Daligault H, Chapman C, Bruce D, Karavis M, McGregor P, Hong C, Park KH, Akmal A, Feldman A, Lin JS, Chang WE, Higgs BH, Demirev P, Lindquist J, Liem A, Fochler E, Tapia R, Bishop-Lilly K, Detter C, Han C, Sozhamannan S, Rosenzweig CN, Skowronski E. Genomic Signatures of Strain Selection and Enhancement in Bacillus atrophaeus var. globigii, a Historical Biowarfare Simulant. PLoS One 2011; 6: e17836

[49] Kang KD, Cho YS, Song JH, Park YS, Lee JY, Hwang KY, Rhee SK, Chung $\mathrm{JH}$, Kwon O, Seong SI. Identification of the genes involved in 1-deoxynojirimycin synthesis in Bacillus subtilis MORI 3K-85. J Microbiol 2011; 431-40 [50] Shibano M, Fujimoto Y, Kushino K; Kusano G, Baba K. Biosynthesis of 1deoxynojirimycin in Commelina communis: a difference between the microorganisms and plants. Phytochemistry 2004; 65:2661-5. 
[51] Shibano, M, Tsukamoto, D, Inoue, T, Takase, Y, Kusano, G. The biosynthesis of Broussonetines: Origin of the carbon skeleton. Chem Pharm Bull 2001; 49: 504-506.

[52] Shibano M, Tsukamoto D, Kusano G. Polyhydroxylated alkaloids with lipohilic moieties as glycosidase inhibitors from higher plants. Heterocycles 2002; 57: 1539-53. [53] Bismut H, Plas C. Role of serine biosynthesis and its utilization in the alternative pathway from glucose to glycogen during the response to insulin in cultured foetal-rat hepatocytes. Biochem J 1991; 276: 577-82.

[54] Kisliuk RL, Sakami W. A study of the mechanism of serine biosynthesis. J Biol Chem 1955; 214: 47-57.

[55] Grobbelaar N, Steward FC. Pipecolic acid in phaseolus vulgaris: Evidence on its derivatives from Lysine. J Am Chem Soc 1953; 75: 4341-3.

[56] Gupta RN, Spenser ID. Biosynthesis of piperidine nucleus J Biol Chem 1969; 244: 88-94.

[57] He M. Pipecolic acid in micxrobes: biosynthetic routes and enzymes. J Ind Microbiol Biotechnol 2006; 33: 401-7.

[58] Guenguerich FP, Broquist HP. In: van Tamelen EE, Ed. Bioorganic Chemistry. New York: Academic press. 1978. 290-312.

[59] Guenguerich FP, Snyder JJ, Broquist HP. Biosynthesis of slaframine (1S,6S,8aS)-1-acetoxy-6-aminooctahydroindolizine, a parasympathomimetic alkaloid of fungal origin. I. Pipecolic acid and salframine synthesis. Biochemistry 1973; 12: 42649.

[60] Guenguerich FP, Broquist HP. Biosynthesis of slaframine (1S,6S,8aS)-1acetoxy-6-aminooctahydroindolizine, a parasympathomimetic alkaloid of fungal origin. II. The origin of pipecolic acid. Biochemistry 1973; 12: 4270-4. 
[61] Clevenstine EE, Broquist HP, Harris TM. Biosynthesis of slaframine (1S,6S,8aS)-1-acetoxy-6-aminooctahydroindolizine, a parasympathomimetic alkaloid of fungal origin. 3. Origin of the pyrrolidine ring. Biochemistry 1979; 18: 3658-63.

[62] Clevenstine EE, Walter P, Harris TM, Broquist HP. Biosynthesis of slaframine (1S,6S,8aS)-1-acetoxy-6-aminooctahydroindolizine, a parasympathomimetic alkaloid of fungal origin. 4. Metabolic fate of ethyl pipecolylacetate, 1,3diocooctahydsroindolizine, and 1-hydroxyoctahydroindolizine in Rhizoctonia leguminicola. Biochemistry 1979; 18: 3663-7.

[63] Guenguerich FP, Dimari SJ, Broquist HP. Isolation and characterization of a 1pyrindine fungal alkaloid. J Am Chem Soc 1973; 95: 2055-6.

[64] Schneider MJ, Ungemach FS, Broquist HP, Harris TM. Biosynthesis of swainsonine in rhizoctonia leguminicola. Epimerization at the ring fusion. J Am Chem Soc 1982; 104: 6863-4.

[65] Harris CM, Schneider MJ, Ungemach FS, Hill JE Harris TM. Biosynthesis of the toxic indolizidine alkaloids slaframine and swainsonine in Rhizoctonia leguminicola: Metabolism of 1-hydroxyindolizidines. J Am Chem Soc 1988; 110: 9409.

[66] Harris CM, Campbell BC, Molyneux RJ, Harris TM. Biosynthesis of swainsonine in the diablo locoweed (astragalus oxyphysus). Tetrahedron Lett 1988; 29: $4815-8$.

[67] Ermayanti TM, McComb JA, O’Brien PA. Stimulation of synthesis and release of swainsonine from transformed roots of swainsona galegifolia. Phytochemistry 1994; 36: $313-7$. 